IJIF

14,1

Received 10 December 2020 Revised 19 December 2020 7 May 2021

20 August 2021

9 September 2021

16 October 2021

Accepted 23 October 2021

\section{Islamic finance and economic growth: the Turkish experiment}

\author{
Mohammed Ayoub Ledhem and Mohammed Mekidiche \\ Department of Economics, University Centre of Maghnia, Maghnia, Algeria
}

\section{Abstract}

Purpose - This study aims to empirically investigate the connection between Islamic finance and economic growth in Turkey using the endogenous growth model.

Design/methodology/approach - It applies quantile regression with the Markov chain marginal bootstrap resampling technique by adopting total Islamic financing as the main exogenous explanatory factor in the endogenous growth model, while the gross domestic product (GDP) is employed as a measure of economic growth. The sample consists of all full-fledged participation (Islamic) banks operating in Turkey spanning from 2013Q4 until 2019Q4. The study uses academic literature, official financial reports from the Participation Banks Association of Turkey, REDmoney Group, Islamic Financial Services Board (IFSB) and the International Monetary Fund (IMF) database.

Findings - The results show that Islamic finance is promoting economic growth in Turkey, which mirrors the success of the New Turkish Economy Program (2019-2021) which aims at boosting economic growth by enhancing the Islamic finance share in the Turkish banking sector and the global market.

Research limitations/implications - Turkey has a dual banking system (conventional and participation (Islamic)) and both can influence the country's real economy. This study is limited to the influence of Islamic banking on Turkish economic growth. The study also restricts its size and coverage from 2013Q4 to 2019Q4, to cover the years over which data for all variables included in the research are available.

Practical implications - This paper suggests the adoption of the Turkish successful experiment as a path to reach economic growth by increasing the Islamic finance share in the banking industry for countries that seek to promote economic growth by Islamic finance, as the findings of this paper support.

Originality/value - This study is the first that examines the influence of Islamic finance on economic growth under a new theoretical framework of the endogenous growth model in Turkey using a robust non-parametric approach.

Keywords Economic growth, Endogenous growth model, Islamic finance, Markov chain marginal bootstrap quantile regression, Non-parametric approach, Participation banks

Paper type Research paper

\section{Introduction}

Turkey has lately become a leading country in Islamic banking and finance (Salaam Gateway, 2020). After more than 30 years since its creation, Turkey's Islamic finance industry has registered notable performance and rapid transformation (Yüksel and Canöz, 2017; Hajjar, 2019). Turkey has become an exemplary country for others that need to increase their Islamic banking and finance market share (Salaam Gateway, 2020). Today, Turkey is in the top 15 countries among Islamic finance's top performers, with a Global Islamic Economy Indicator rating of 55.9 (Salaam Gateway, 2021).

(C) Mohammed Ayoub Ledhem and Mohammed Mekidiche. Published in ISRA International Journal of Islamic Finance. Published by Emerald Publishing Limited. This article is published under the Creative Commons Attribution (CC BY 4.0) licence. Anyone may reproduce, distribute, translate and create derivative works of this article (for both commercial and non-commercial purposes), subject to full attribution to the original publication and authors. The full terms of this licence may be seen at http:// creativecommons.org/licences/by/4.0/legalcode

The authors would like to thank the General Directorate of Scientific Research and Technological Development under the the Algerian Ministry of Higher Education and Scientific Research for supporting this research. The authors would also like to thank the Laboratory for Money and Financial Institutions in the Arab Maghreb for the continuous support of research. 
Islamic finance in Turkey is defined as participation banking based on the Islamic finance concept of participation in profit and loss (Hajjar, 2019). At the end of 2020, six participation (Islamic) banks (henceforth called participation banks (PBs)) were involved in the banking industry, which contains a total of 54 banks: 34 savings banks, 14 investment banks and 6 PBs (Participation Banks Association of Turkey, 2021a). Based on the date of creation, these PBs are Albaraka Türk, Kuveyt Türk, Ziraat Katılım, Türkiye Finans, Vakıf Katılım and Emlak Katılım. They operate all types of banking activities in full compliance with Sharíah (Islamic law) principles of interest-free banking (Participation Banks Association of Turkey, 2021a).

The interest-free principle is applied using, among others, the muräbahah contract, in which the bank purchases products that the customers want from vendors and sells them to the customers on instalments. Financing is also provided based on partnership and lease contracts (Participation Banks Association of Turkey, 2020). In addition to avoidance of interest, participation finance observes the avoidance of uncertainty in contracts and the prohibition of unnecessary risk and betting (Participation Banks Association of Turkey, 2020).

According to the Islamic Financial Services Board (IFSB) (2020), the share of Turkish PBs in the worldwide Islamic finance market was $2.9 \%$ in 2016. Lately, according to the Participation Banks Association of Turkey (2021a), Turkish participation banking has been growing fast, recording an increased net profit of $16 \%$, from TL2.4bn (US $\$ 278.06 \mathrm{~m}$ ) in 2019 to TL3.7bn (US $\$ 428.68 \mathrm{~m}$ ) in 2020. The fast growth of participation banking in Turkey is translated in the increase of total accumulated assets of TL437.1bn (US\$50.64bn) in 2020 as compared to TL284.5bn (US\$32.96bn) in 2019. As a result, Turkey ranked 7 th among the top countries with the highest Islamic banking assets, with a global share of $2.6 \%$ and a domestic banking share of 7.1\% as at 2019Q3 (Participation Banks Association of Turkey, 2021a).

While the participation banking penetration ratio in Turkey reached $7.1 \%$ in October 2020, the strategy of participation banking in Turkey (2021-2025) is to achieve a market share of 15\% by 2025 (Participation Banks Association of Turkey, 2021b). This strategy of growing the Islamic finance share in Turkey is based on the government's New Turkish Economy Program 2019-2021. It is expected that the Islamic finance share in Turkey will be tripled through PBs, from $5 \%$ to $15 \%$ by 2025, to enhance economic growth in Turkey (McAughtry, 2019; Participation Banks Association of Turkey, 2020). Consequently, this expected growth of Islamic finance assets, which reflects the potential of PBs in the Turkish economy, motivates this study to empirically examine whether Islamic finance in Turkey is contributing to economic growth, as planned under the New Turkish Economy Program 2019-2021.

This paper answers the following question: Does Islamic finance promote economic growth in Turkey? It seeks to answer it by employing the endogenous growth model. The objective is to provide empirical evidence for financial scholars, academicians and decisionmakers on the importance of Islamic finance as an engine of economic growth.

The rest of this study is organized as follows: the literature review and the gap of the study are discussed in the following section. Next, the sample and collected data, the proposed empirical model and the method of analysis are presented. The findings are then deliberated. The conclusion and implications of this study are finally provided.

\section{Literature review \\ Islamic finance in Turkey}

The practice of Islamic finance in Turkey started with foreign-owned PBs setting up subsidiaries in the country. It commenced in 1985 with the setting up of Albaraka Türk PB. The second foreign-owned PB is Kuwait Turkish PB (Kuveyt Türk) which commenced operations in 1989 (Hajjar, 2019). In 2020, Kuveyt Türk became the biggest PB in Turkey based on assets volume (Participation Banks Association of Turkey, 2021a).

Eventually, locally owned Turkish banks also entered the field of Islamic finance. The participation banking sector was joined by Türkiye Finans in 2005, Ziraat Katilim in 2015,

Islamic finance and economic growth 
IJIF

14,1

6

Table 1.

Turkish PBs' market net profits as at end-2020 share, total assets and

Vakif Katilim in 2016 and Emlak Katilim in 2019. Overall, Islamic finance in Turkey continued to grow through the six PBs, witnessing high growth in assets and net profits in 2020 as shown in Table 1.

\section{Islamic finance as a path to economic growth under the New Turkish Economy Program (2019-2021)}

Islamic finance in Turkey - as one of the core elements of the Turkish economy - proved to be a significant factor of growth and development as it continued to sustain its position in the financial sector with its strong performance. Total Islamic assets have been rising over the period 2013Q4-2019Q4, synchronizing the growth in GDP, as shown in Figure 1. The New Turkish Economy Program (2019-2021) plans to further promote economic growth through the stimulation of Islamic finance by increasing the share of participation banking from $5 \%$ to $15 \%$ by 2025 (McAughtry, 2019; Participation Banks Association of Turkey, 2020; Tan, 2020).

\section{Theoretical background of Islamic finance and economic growth under the endogenous growth model}

Romer's endogenous growth theory became well known in the 1980s. The model argues that the permanent rate of growth is well determined by variables under the model, not by the exogenous pace of technological progress as in the neoclassical growth model (Romer, 2011). The endogenous growth model supports technical progression evolving from the investment level and the size of human capital stock (Jhingan, 2011). Moreover, development finance contributes to economic growth as an exogenous factor inside the model of endogenous

\begin{tabular}{lcll}
\hline Participation bank & Market share & Total assets & Net profits \\
\hline Albaraka Türk & $16 \%$ & TL69.3bn (US $\$ 8.03 \mathrm{bn})$ & TL63.4m (US\$7.35m) \\
Kuveyt Türk & $36 \%$ & TL152.3bn (US $\$ 17.65 \mathrm{bn})$ & TL1400.3m (US\$162.24m) \\
Türkiye Finans & $19 \%$ & TL81.4bn (US\$9.43bn) & TL675.7m (US $\$ 78.29 \mathrm{~m}$ ) \\
Ziraat Katilim & $13 \%$ & TL60.2bn (US\$6.97bn) & TL254.7m (US $\$ 29.51 \mathrm{~m}$ ) \\
Vakif Katilim & $13 \%$ & TL53.2bn (US\$6.16bn) & TL666.9m (US\$77.27m) \\
Emlak Katilim & $4 \%$ & TL81.4bn (US\$9.43bn) & TL80.6m (US\$9.34m) \\
Source(s): Participation Banks Association of Turkey (2021a, b). & \\
\hline
\end{tabular}

Figure 1.

The growth of Islamic finance assets alongside gross domestic product (GDP) over the period 2013Q4-2019Q4 (Million TL)

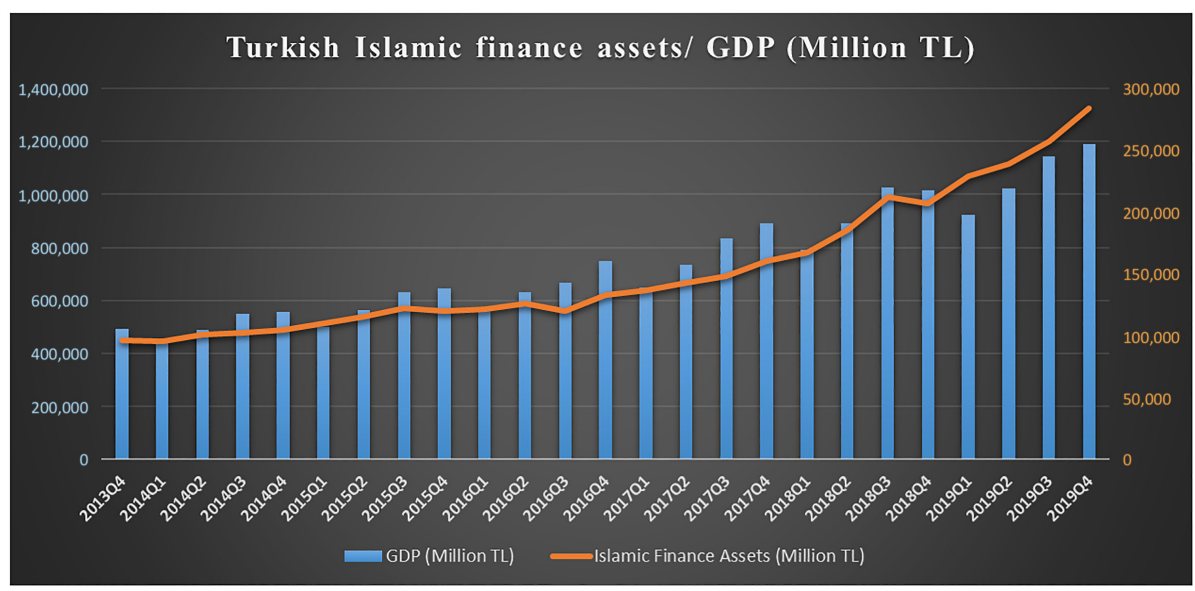

Source(s): Prepared by authors based on extracted data from IFSB(2020) and International Monetary Fund (2020) 
growth, as has been confirmed by the notable studies of King and Levine (1993), Rajan and Zingales (1996), Levine and Zervos (1998) and Hassan et al. (2011).

According to the endogenous growth theory, when investment in the finance industry increases, it advances economic growth, as confirmed by Petkovski and Kjosevski (2014). Additionally, Bourke (1989) informed that banks with a large profitability remain highly capitalized and have quick access to capital. As a result, the surge in capital stock from banking and finance leads to notable economic growth.

As well, Tabash and Anagreh (2017) stated that Islamic finance has enhanced investment and economic growth. Besides, Kassim (2016), Boukhatem and Moussa (2018), Ledhem (2020), Ledhem and Mekidiche (2020) and Ledhem and Moussaoui (2021) confirmed that economic growth is endorsed by the factor of Islamic finance, which has been used as an exogenous factor within the endogenous growth model.

In summary, endogenous economic growth is defined exogenously by Islamic finance due to its weighty influence on rising capital stock and investment. This connection between Islamic finance and economic growth is in fact a continuation of the supply-leading hypothesis of Schumpeter (1934). It is also in line with the financial repression philosophy of McKinnon (1973) and Shaw (1973), which argues that financial development leads to economic growth. For this reason, this study explores the influence of Islamic finance on economic growth under the endogenous growth model in Turkey.

Based on the philosophy of the endogenous growth theory, which determines that growth in Islamic finance leads to economic growth, this study formulates the following hypothesis:

H1. Economic growth is affected positively by Islamic finance in Turkey.

\section{Prior empirical studies}

Numerous studies have been conducted on the connection between Islamic finance and economic growth. Regarding international studies that found a positive effect of Islamic finance on economic growth, a recent study by Gani and Bahari (2021) used autoregressive distributive lags (ARDL) to determine the causal effect of Islamic finance on economic growth from 1998 to 2017 in Malaysia. Their findings revealed that Islamic finance is enhancing Malaysian economic growth.

In another recent study, Ledhem and Moussaoui (2021) explored the nexus between Islamic finance for the entrepreneurial domain and economic growth from 2014 to 2019 in Malaysia. They employed Granger causality and quantile regression using quarterly periods. Their outcomes confirmed that Islamic finance is significantly promoting economic growth in Malaysia by financing entrepreneurial activities.

In the same vein, Anwar et al. (2020) explored whether Islamic finance is promoting Indonesian economic growth from 2009Q1 to 2019Q4. They employed vector error correction model (VECM), functions of the impulse response and the ARDL approach to investigate the connection between Islamic finance and economic growth. They found a weighty link between Islamic finance and Indonesian economic growth.

In general, there are a number of past studies which examined the influence of Islamic finance on economic growth in different countries, some of which are highlighted below:

(1) Furqani and Mulyany (2009) assessed Islamic finance's interactions with Malaysian economic growth by applying the cointegration approach and VECM;

(2) Abduh and Omar (2012) studied the Islamic finance effect on Indonesian economic growth by applying the ARDL cointegration methodology;

(3) Mohd. Yusof and Bahlous (2013) assessed Islamic finance's influence on economic growth in the region of the Gulf Cooperation Council (GCC), Indonesia and Malaysia using variance decompositions (VDCs) panel cointegration analysis;

Islamic finance and economic growth 
IJIF

14,1

8

(4) Farahani and Dastan (2013) investigated the Islamic finance effect on economic growth using international evidence;

(5) Kassim (2016) studied the case of Malaysia by employing the ARDL approach over the sample period 1998-2013;

(6) Lebdaoui and Wild (2016) investigated the connection between economic growth and Islamic banks in Southeast Asia using panel ARDL and panel two-stage least squares method on quarterly data from 2000 to 2012;

(7) Imam and Kpodar (2016) explored whether Islamic finance's progress is boosting economic growth, using a system generalized method of moments estimation and fixed-effect regression on 52 countries spanning from 1990 to 2010; and

(8) Boukhatem and Moussa (2018) presented strong evidence that Islamic finance boosted economic development in 13 countries of the Middle East and North Africa (MENA) by using fully modified ordinary-least-squares regression and panel cointegration over the period 2000-2014.

However, to the best of the authors' knowledge, studies on the connection between Islamic finance and economic growth in Turkey are limited. Moreover, no study has yet investigated the connection under the new theoretical framework of the endogenous growth model.

Regarding notable studies that determined a positive influence of Islamic finance on Turkish economic growth, Atici (2018) explored the causality between Islamic finance and economic growth over the period 2008Q1-2018Q1 using the VECM approach. Similarly, Kalaysi and Tekin (2016) explored the interactions between Islamic finance's development and economic growth in Turkey. They used the Johansen cointegration method and Granger causality over the period 2002-2014. Both Kalaysi and Tekin (2016) and Atici (2018) found a positive Islamic finance influence on Turkish economic growth; thus, the supply-leading hypothesis of Schumpeter (1934) was validated.

In the same vein, Yüksel and Canöz (2017) examined the influence of Islamic finance on Turkish economic growth by applying Granger causality on quarterly data between 2005 and 2016. They used GDP as a measure of economic growth and financing as the main factor for Islamic finance effectiveness. They investigated the link between Islamic finance and economic growth based on only four PBs that had a low share in the banking sector at the time of the study (4.9\% in 2016, according to the Participation Banks Association of Turkey (2017)). Therefore, they found that Islamic finance is not affecting economic growth in Turkey due to the low share of PBs in the banking sector. The authors' finding is consistent with Lucas' (1988) neutrality theory, which claims that the finance-development link is overstressed because it is not a significant factor in the growth cycle.

The conflicting results from the two groups of studies in the context of Turkey have brought about a debate among scholars over the actual contribution of Islamic finance to economic growth in Turkey. For this reason, this study attempts to enrich the literature with a better understanding of whether the growth of Islamic finance in the Turkish banking sector has been a real factor for promoting economic growth in Turkey.

\section{Research methodology}

\section{Sample and data collection}

This paper employed Islamic finance data from six PBs (Albaraka Türk, Kuveyt Türk, Ziraat Katılım, Türkiye Finans, Vakıf Katilim, and Emlak Katilim) in Turkey. Data were obtained from quarterly statistics in the database of the IFSB (2020) over the period 2013Q4-2019Q4. 
Other macroeconomic variables of Turkey like the GDP, gross fixed capital formation (GFCF) and trade openness (TRADE) were obtained from the database of the International Monetary Fund (2020).
Islamic finance and economic growth

\section{Variables}

With regard to the economic growth variable, this study followed the studies of Furqani and Mulyany (2009), Abduh and Omar (2012), Farahani and Dastan (2013) and Yüksel and Canöz (2017) in employing the GDP of Turkey as a measure of economic growth. With regard to the Islamic finance variable, this study adopted the same approach as the cited studies and employed total Islamic financing (IFIN) in Turkey as the main independent exogenous variable.

As regards the macroeconomics variables (control variables), it followed Kassim (2016) and used GFCF and TRADE to control the empirical investigation and avoid the problem of biases in the estimated model which arise due to mislaid variables. TRADE, which represents the external sector, was employed as a proxy of trade activities (Furqani and Mulyany, 2009; Farahani and Dastan, 2013; Kassim, 2016). It was measured by the sum of Turkish imports and exports over Turkish GDP. GFCF was employed as a measure of investment, which is one of the main channels used by financial intermediaries that may promote economic growth (Furqani and Mulyany, 2009; Abduh and Omar, 2012; Kassim, 2016).

\section{Estimating model}

The essential issue in the estimation model of economic growth is the inclusion of the most appropriate control variables. Brock and Durlauf (2001) addressed this issue of including the control variables in the estimation model as an "open-ended theory" due to the causal connection between any control variable and economic growth. This theory detailed that controlling the connection between economic growth and a further variable is difficult to regulate. Certainly, this theory was confirmed before by Durlauf and Quah (1999) when they presented about 90 possible variables for controlling economic growth.

However, the key goal in this paper is not to mention all theories of economic growth related to Islamic finance but rather to explore whether and how Islamic finance influences economic growth in the context of the endogenous growth model. Consequently, this study determined the minimal model for the estimation of Islamic finance's influence on economic growth. Thus, following previous empirical studies associated with the topic, it employed the probable macro-economic factors as control variables to prevent the bias problem in the estimation model. Hence, the general model for the empirical investigation is provided in equation (1):

$$
\mathrm{GDP}=\mathrm{IFIN}+\mathrm{GFCF}+\mathrm{TRADE}
$$

where GDP is a dependent variable, IFIN is an independent variable and GFCF and TRADE are control variables.

\section{Econometric methodology}

According to Ullah (1989) and Jureckova et al. (2012), the non-parametric approaches are efficient for empirical investigation because these approaches do not require parametric distributions for the produced errors from the estimation models. As well, the non-parametric approaches provide a profound and accurate mathematical explanation, which is better than the parametric approaches that can generate misleading estimated results because of the assumption that the generated errors in the estimation model follow parametric distributions. According to Machado et al. (2019), one of the robust non-parametric approaches is quantile 
IJIF

14,1

regression. Thus, following the studies which adopt the non-parametric approach of quantile regression regarding the nexus of finance and economic growth, Abdel-Razzaq (2018) used this approach to examine the determinants of Islamic banking profitability with macroeconomic variables like GDP. Also, using the non-parametric approach of quantile regression in the domain of banking, Jiang et al. (2019) estimated the connection between the capital cushion and risk-holding in the banking sector. This experimental study applied quantile regression with the bootstrap technique over 1,000 simulations for a robust estimation.

The quantile regression procedure was presented by Koenker and Bassett (1978). Machado and Silva (2013) and Machado et al. (2019) indicated that quantile regression was adopted in many practical applications. It leads to robust estimation without the heteroskedasticity problem when the dependent variable has varied properties on the conditional distribution over the independent variable.

Following Koenker and Bassett (1978), the $\tau$ quantile conditional distribution of the variable $Y_{i}$ given $X_{i}$ is provided in equation (2):

$$
Q_{\tau}\left(Y_{i} \mid X_{i}\right)=X_{i}^{\prime} \beta_{\tau}
$$

The $\tau$ quantile's restriction vector among the conditional distribution is valued via:

$$
\widehat{\beta}_{\tau}=\operatorname{argmin} \sum_{i=01}^{N} \rho_{\tau}\left(Y_{i}-X_{i}^{\prime} \beta\right)
$$

where $\rho_{\tau}$ (.) is the quantile loss function and is defined as:

$$
\begin{gathered}
\rho_{\tau}(u)=(\tau-1) u \text { for } u<0 \\
\rho_{\tau}(u)=\tau u \text { for } u \geq 0
\end{gathered}
$$

Equation (3) shows that the method of quantile regression allows for restraint heterogeneity with various $\tau$ values in the interval $(0,1)(\tau \in[0,1])$, in which these values are the minimum weighted deviations sum, which allows getting more detailed analysis of the link between an exogenous variable $\left(X_{i}\right)$ and endogenous variable $\left(Y_{i}\right)$ in the interval $(0,1)$ (Koenker and Machado, 1999; Jiang et al., 2019; Machado et al., 2019).

Besides, the quantile regression is robustly precise with regard to outliers since it can adjust the weight over the loss function $\left(\rho_{\tau}\right)$. Unlike the ordinary least squares approach, the quantile process is not limited to the standard error (SE) term (Koenker and Machado, 1999; Jiang et al., 2019; Machado et al., 2019).

As stated by Hahn (1995), Feng et al. (2011) and Nikitina et al. (2019), when the sample in the empirical model that uses the quantile regression is small, it is better to employ bootstrapping as an efficient technique for robust resampling to get healthy estimated results. Kocherginsky et al. (2005) also recommended the Markov chain marginal bootstrap (MCMB-A) resampling technique for the quantile regression that has a finite and small sample. Thus, since the research sample is small with 25 observations, this research applied the quantile regression with MCMB-A resampling technique. This technique was developed by Kocherginsky and He (2007) after it was previously used by $\mathrm{He}$ and $\mathrm{Hu}$ (2002) and Kocherginsky et al. (2005). Besides, according to Kocherginsky et al. (2005), the MCMB-A is robust and accurate against heteroskedasticity.

According to Kocherginsky and He (2007), the MCMB-A resampling technique is created by resampling with separate replacement from the residuals $u_{\mathrm{i}}(\tau)$ and from $X_{i}$. By letting $u^{*}$ be a resample residual $\mathrm{m}$-vector and letting $X^{*}$ be an exogenous (independent) resample matrix of $m \times p\left(m \neq n\right.$ where $n$ is the sample size), the endogenous (dependent) variable $Y^{*}$ (using the resampled residuals, resampled data and estimated coefficients) is as follows: 


$$
Y^{*}=X^{*} \widehat{\beta}(\tau)+u^{*} .
$$

Then, using $X^{*}$ and $Y^{*}$, the bootstrap estimation of $\beta(\tau)$ is constructed under the repeated process for $M$ (chain length) bootstrap simulations, and the estimated form for the asymptotic covariance-matrix $V(\widehat{\beta})$ is as follows:

$$
V(\widehat{\beta})=n\left(\frac{m}{n}\right) \frac{1}{B} \sum_{j=1}^{B}(B j(\tau)-\overline{B(\tau)})(B j(\tau)-\overline{B(\tau)})^{\prime}
$$

\section{Islamic finance} and economic growth

where $\overline{B(\tau)}$ is the bootstrap elements mean and the bootstrap covariance-matrix $V(\widehat{\beta})$ is purely an estimation of the sample's variance of the bootstrap estimations $\widehat{\beta}(\tau)$ (Kocherginsky and He, 2007). The estimated model using the quantile regression in this study is as follows:

$$
\mathrm{GDP}_{t}=\alpha_{\tau}+\alpha_{\tau 1} \mathrm{IFIN}_{t}+\alpha_{\tau 2} \mathrm{GFCF}_{t}+\alpha_{\tau 3} \mathrm{TRADE}_{t}, \tau \in(0,1)
$$

where $\alpha_{\tau}$ is the constant (C) term; $\alpha_{\tau 1}, \alpha_{\tau 2}$ and $\alpha_{\tau 3}$ are coefficients; $t$ is the quarter; GDP is the dependent variable; IFIN is the independent variable; and GFCF and TRADE are control variables.

This study applied the quantile regression quantiles with the MCMB-A resampling technique over 1,000 simulations to determine the influence of IFIN as the main exogenous variable on GDP as the endogenous variable.

\section{Results and discussion}

According to Koenker and Bassett (1978), quantile regression is an extension of linear least squares regression that estimates the response variable's conditional mean across values and the independent variables. Thus, it is important to test the linearity of the structure and stationarity of the variables which confirm that the estimated model is fit to the autoregressive (AR) process.

To check the linearity, this paper performed the test of Keenan (1985) and Tsay (1986) and the likelihood ratio linearity test of Chan and Tong (1986) (Table 2). It also performed the augmented Dickey-Fuller (ADF) test to check the variables' stationarity to avoid the issue of spurious regression (Granger et al., 1974; Leong and Huang, 2010) (Table 3).

Table 2 shows that the null hypothesis cannot be rejected at the $5 \%$ significance level in the tests of Keenan (1985) and Tsay (1986) and the likelihood ratio linearity test of Chan and Tong (1986). This confirms that all the variables in this research are proven to be of linear characteristics. Thus, GDP, IFIN, TRADE and GFCF follow the linear AR process.

Based on the ADF test, Table 3 shows that the AR(1) coefficient of GDP, IFIN, TRADE and GFCF series are statistically significant at the $1 \%$ level, which indicates that GDP, IFIN,

\begin{tabular}{lccccrr}
\hline $\begin{array}{l}\text { Null hypothesis: The model is an autoregressive (AR) process (linear structure) } \\
\text { Keenan (1985) one-degree }\end{array}$ & \multicolumn{2}{c}{ Tsay (1986) test } & \multicolumn{2}{c}{$\begin{array}{c}\text { Likelihood ratio } \\
\text { linearity test } \\
\text { test }\end{array}$} \\
$\begin{array}{l}\text { Linearity test } \\
\text { Variables }\end{array}$ & $t$-stat & Prob. & $t$-stat & Prob. & $t$-stat & Prob. \\
\hline GDP & 0.1403664 & 0.7116738 & 0.003549 & 0.9531 & 6.160 & 0.328 \\
IFIN & 0.07369802 & 0.7886775 & 2.088 & 0.1632 & 10.791 & 0.195 \\
TRADE & 2.175466 & 0.1550628 & 0.6671 & 0.4232 & 4.568 & 0.324 \\
GFCF & 0.8390086 & 0.3700798 & 0.04532 & 0.8335 & 8.642 & 0.293
\end{tabular}

Source(s): Authors' own
Table 2 . Linearity test outputs 


\section{IJIF \\ 14,1}

\begin{tabular}{|c|c|c|c|c|}
\hline Variables & Stationarity levels & No trend, no intercept & $\begin{array}{c}P \text {-value } \\
\text { Including intercept }\end{array}$ & $\begin{array}{l}\text { Including trend and } \\
\text { intercept }\end{array}$ \\
\hline \multirow[t]{2}{*}{ GDP } & Level & 0.9964 & 0.8879 & 0.8356 \\
\hline & 1st difference & $0.0000^{* *}$ & $0.0000^{* *}$ & $0.0000^{* *}$ \\
\hline \multirow[t]{2}{*}{ IFIN } & Level & 0.9967 & 0.8962 & 0.9367 \\
\hline & 1st difference & $0.0041^{* *}$ & $0.0008^{* *}$ & $0.0035^{* *}$ \\
\hline \multirow[t]{2}{*}{ TRADE } & Level & 0.9458 & 0.4467 & 0.6660 \\
\hline & 1st difference & $0.0000^{* *}$ & $0.0000^{* *}$ & $0.0000^{* *}$ \\
\hline \multirow[t]{2}{*}{ GFCF } & Level & 0.8998 & 0.3260 & 0.0647 \\
\hline & 1st difference & $0.0000^{* *}$ & $0.0000^{* *}$ & $0.0001^{* *}$ \\
\hline
\end{tabular}

Table 3.

Note(s): ${ }^{* *} 1 \%$ significance level

Stationarity tests using Source(s): ADF test executed by authors based on the Akaike information criterion (AIC) for choosing the the $\mathrm{ADF}$ test optimal lag length

Table 4.

MCMB-A quantile regression outputs
Number of observations $=25$

$R$-squared $=0.856641$

$\mathrm{SE}$ of regression $=41589.67$

Quasi-LR statistic $=154.1845$

\begin{tabular}{lccrc}
\hline Variables & Coefficient & Stand. Err. & $t$-stat & Prob. \\
\hline IFIN & 4.977824 & 1.279755 & 3.889670 & $0.0008^{* * *}$ \\
TRADE & -497400.9 & 241112.6 & -2.062940 & $0.05177^{* *}$ \\
GFCF & 1.711026 & 0.523311 & 3.269615 & $0.0037^{*}$ \\
C & 145063.7 & 103246.6 & 1.405022 & 0.1746
\end{tabular}

Note(s): MCMB-A quantile regression with 1,000 simulations; number of observations $=25$; ${ }^{* *} 1 \%$ significance level

Source(s): Quantile regression outputs computed by the authors

TRADE and GFCF do not contain a unit root in the first difference. Therefore, all the variables in this study are stationary and follow the linear AR(1) process, which indicates that the problem of spurious regression does not exist (Granger et al., 1974; Leong and Huang, 2010).

To obtain robust estimated results, this paper performed the quantile regression with the MCMB-A (Table 4).

Table 4 reports that Islamic finance in Turkey has a positive influence on economic growth at the $1 \%$ significance level ( $p$-value: $0.0008<0.01$ ). If there is an increase of $1 \%$ in Islamic finance median value, then GDP will increase by $4.97 \%$ in the median value. Thus, this outcome validates the hypothesis that Islamic finance is positively affecting economic growth in Turkey.

For trade openness (TRADE), it has no significant effect on GDP in Turkey at the 5\% significance level ( $p$-value: $0.0517>0.05)$. On the other hand, GFCF is positively influencing economic growth (GDP) in Turkey at the $1 \%$ significance level ( $p$-value: $0.0037<0.01$ ). If there is an increase of $1 \%$ in GFCF median value, then GDP will increase by $1.71 \%$ in the median value. For the constant (C), it is not significant to economic growth since the $p$-value is superior to 0.05 , which confirms the high explanatory power of the independent variables in the estimated model $\left(R^{2}=0.8566\right)$.

Concerning the quantile regression goodness-of-fit tests as defined by Koenker and Machado (1999), Table 4 shows that the $R$-squared is $85.66 \%$ and the adjusted $R$-squared is $83.61 \%$. So, $83.61 \%$ variation in the conditional median in GDP is due to IFIN, TRADE and 
GFCF. The quasi-LR statistic value is 154.1845 and the $p$-value $(0.000)$ is less than 0.05 , which indicates that the estimated model is stable.

To determine the quantile process estimates, Table 5 provides estimates across $0.1,0.2,0.3$, $0.4,0.5,0.6,0.7,0.8$ and 0.9 quantiles. Lower quantiles (from quantile $=0.10$ to quantile $=0.30$ ) represent low Islamic finance (IFIN) on a low economic growth (economic recession), the medium quantiles (from quantile $=0.30$ to quantile $=0.70$ ) reflect medium Islamic finance (IFIN) on medium economic growth and the upper quantiles (from quantile $=0.70$ to quantile $=0.90)$ represent high Islamic finance (IFIN) on high economic growth.

Table 5 reports that GDP is increased by IFIN from $4.48 \%$ in the 40 th quantile $(0.4$ quantiles) to $8.84 \%$ in the 90 th quantile ( 0.9 quantiles), which indicates that IFIN is increasing GDP in medium and high quantiles. Therefore, these increases in Islamic finance are causing a significant increase in the Turkish economic growth. This outcome is in accordance with the findings of Imam and Kpodar (2016) which state that when Islamic finance is increased in a
Islamic finance and economic growth

\begin{tabular}{|c|c|c|c|c|c|}
\hline Variables & Quantile & Coefficient & Stand. Err. & $t$-stat & Prob. \\
\hline \multirow[t]{9}{*}{ IFIN } & 0.1 & 2.922687 & 1.675404 & 1.744467 & 0.0957 \\
\hline & 0.2 & 2.961143 & 1.962144 & 1.509136 & 0.1462 \\
\hline & 0.3 & 3.138609 & 1.538276 & 2.040342 & 0.0541 \\
\hline & 0.4 & 4.485209 & 1.557342 & 2.880040 & $0.0090^{* *}$ \\
\hline & 0.5 & 4.977824 & 1.266206 & 3.931292 & $0.0008^{* *}$ \\
\hline & 0.6 & 5.086412 & 2.660126 & 1.912094 & 0.0696 \\
\hline & 0.7 & 5.342965 & 0.868275 & 6.153538 & $0.0000^{\text {** }}$ \\
\hline & 0.8 & 5.070640 & 1.198040 & 4.232448 & $0.0004^{* *}$ \\
\hline & 0.9 & 8.844035 & 0.030780 & 287.3287 & $0.0000^{* * *}$ \\
\hline \multirow[t]{9}{*}{ TRADE } & 0.1 & -403711.7 & 374090.5 & -1.079182 & 0.2927 \\
\hline & 0.2 & -38895.40 & 420364.7 & -0.092528 & 0.9272 \\
\hline & 0.3 & -151071.2 & 340439.0 & -0.443754 & 0.6618 \\
\hline & 0.4 & -531977.6 & 325410.9 & -1.634787 & 0.1170 \\
\hline & 0.5 & -497400.9 & 239479.8 & -2.077005 & 0.0503 \\
\hline & 0.6 & -500723.2 & 279847.9 & -1.789269 & 0.0880 \\
\hline & 0.7 & -445406.0 & 157957.7 & -2.819781 & $0.0103^{*}$ \\
\hline & 0.8 & -402915.7 & 203050.4 & -1.984314 & 0.0604 \\
\hline & 0.9 & -842152.4 & 7709.936 & -109.2295 & $0.0000^{* *}$ \\
\hline \multirow[t]{9}{*}{ GFCF } & 0.1 & 1.861790 & 0.563808 & 3.302170 & $0.0034^{* *}$ \\
\hline & 0.2 & 2.066955 & 0.718605 & 2.876343 & $0.0090^{* *}$ \\
\hline & 0.3 & 2.085699 & 0.586728 & 3.554800 & $0.0019^{* *}$ \\
\hline & 0.4 & 1.905347 & 0.621343 & 3.066498 & $0.0059^{* *}$ \\
\hline & 0.5 & 1.711026 & 0.515568 & 3.318720 & $0.0033^{* *}$ \\
\hline & 0.6 & 1.609310 & 1.211872 & 1.327955 & 0.1984 \\
\hline & 0.7 & 1.496799 & 0.342440 & 4.370976 & $0.0003^{* *}$ \\
\hline & 0.8 & 1.613730 & 0.433668 & 3.721121 & $0.0013^{* *}$ \\
\hline & 0.9 & 0.286724 & 0.012793 & 22.41241 & $0.0000^{* *}$ \\
\hline \multirow[t]{9}{*}{$\mathrm{C}$} & 0.1 & 212276.8 & 133152.6 & 1.594237 & 0.1258 \\
\hline & 0.2 & -6076.873 & 151230.9 & -0.040183 & 0.9683 \\
\hline & 0.3 & 34754.33 & 136189.7 & 0.255191 & 0.8011 \\
\hline & 0.4 & 166119.1 & 135113.1 & 1.229482 & 0.2325 \\
\hline & 0.5 & 145063.7 & 102333.4 & 1.417560 & 0.1710 \\
\hline & 0.6 & 161970.0 & 125698.3 & 1.288562 & 0.2116 \\
\hline & 0.7 & 137645.2 & 68811.09 & 2.000335 & 0.0586 \\
\hline & 0.8 & 119727.0 & 86123.51 & 1.390178 & 0.1790 \\
\hline & 0.9 & 283469.1 & 3577.046 & 79.24671 & $0.0000^{* *}$ \\
\hline
\end{tabular}

Note(s): MCMB-A quantile regression with 1,000 simulations; number of observations $=25 ;{ }^{*} 5 \%$ significance level; ${ }^{* *} 1 \%$ significance level

Source(s): Quantile regression outputs computed by the authors

Table 5. Markov chain marginal bootstrap (MCMB-A) quantile process estimates 
IJIF

14,1

14

country, it experiences quicker economic growth (Figure 2). Consequently, the hypothesis that Islamic finance is positively affecting economic growth in Turkey is validated.

Moreover, the success of IFIN in enhancing GDP refers to the Islamic finance growth in Turkey which synchronized a high level of economic growth because of PBs. It is noted that PBs increased their total assets by $21.9 \%$ from December 2018 to August 2019 based on the prospects of the New Turkish Economy Program (2019-2021), which forecasted an increase in the Islamic finance share through PBs from 5\% to 15\% by 2025 (McAughtry, 2019; Participation Banks Association of Turkey, 2020; Tan, 2020). Thus, the New Turkish Economy Program (2019-2021), which aims at stimulating Islamic finance to achieve significant economic growth, can be said to be successful. However, IFIN in Turkey has no significant influence on economic growth across low quantiles of $(0.1,0.2$, and 0.3 quantiles), consistent with the findings of Yüksel and Canöz (2017) (Figure 2).

Concerning other control variables, TRADE has no significant effect on economic growth in Turkey across lower quantiles (0.1, 0.2 and 0.3 quantiles), medium quantiles (0.4, 0.5 and 0.6 quantiles) and upper quantiles (0.8 quantiles) (Figure 2). Regarding GFCF, Table 5 reports that GFCF is contributing to GDP all over the lower quantiles (0.1, 0.2 and 0.3 quantiles), medium quantiles (0.4, 0.5 and 0.7 quantiles) and upper quantiles ( 0.8 and 0.9 quantiles) (Figure 2). For the constant (C), it has no significant effect on Turkish economic growth across lower quantiles (0.1, 0.2 and 0.3 quantiles), medium quantiles $(0.4,0.5$, and 0.6 quantiles) and upper quantiles ( 0.7 , and 0.8 quantiles).

Regarding diagnostics of the estimation model based on Koenker and Machado (1999), quantile regression requires that the following tests be performed: Koenker and Bassett's slope equality examination (1982), Ramsey's reset stability test (1969) and Newey and Powell's symmetric quantile assessment (1987) (Table 6).

Table 6 reports that the $\mathrm{chi}^{2}$-statistic value is 47.00640 which is statistically significant under the slope equality examination (probability of $\chi^{2}: 0.0033<0.05$ which indicates that

\section{Quantile Process Estimates}

IFIN

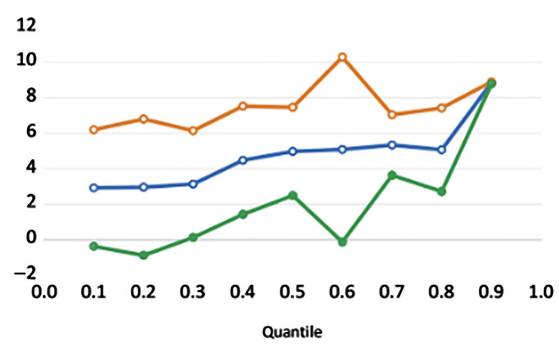

GFCF

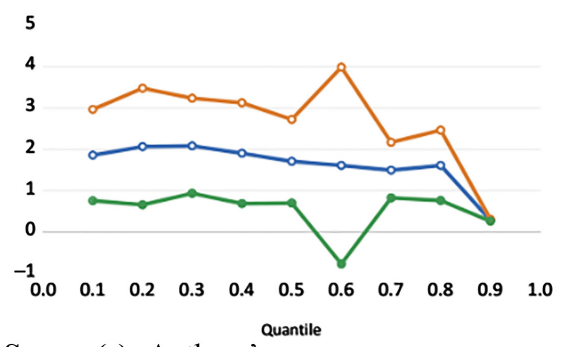

Source(s): Authors' own
Figure 2.

Markov chain marginal bootstrap (MCMB-A) quantile process estimates graphs
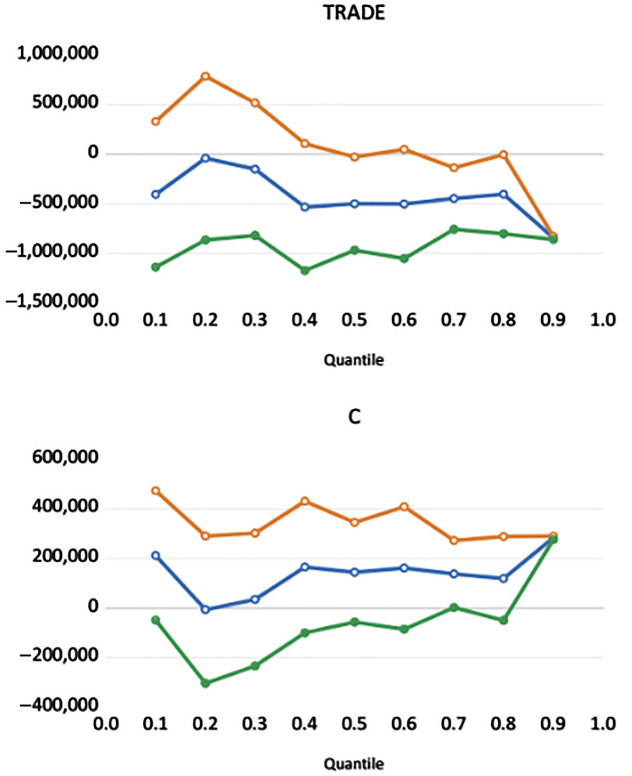
Slope equality examination

Null hypothesis: Slope equality is identical

\begin{tabular}{|c|c|c|c|}
\hline Test summary & $\chi^{2}$ stat & $\chi^{2}$ D.F. & Prob. \\
\hline Wald test & 47.00640 & 24 & 0.0033 \\
\hline \multicolumn{4}{|c|}{$\begin{array}{l}\text { Ramsey's reset stability test } \\
\text { Null hypothesis: No misspecification in the model }\end{array}$} \\
\hline Test summary & Value & D.F. & Prob. \\
\hline QLR L-statistic & 2.508520 & 1 & 0.1132 \\
\hline
\end{tabular}

Symmetric quantile assessment

Null hypothesis: No asymmetry in quantiles

\begin{tabular}{lccr} 
Test summary & $\chi^{2}$ statistic & $\chi^{2}$ D.F. & Prob. \\
\hline Wald test & 12.95808 & 16 & 0.6758
\end{tabular}

\begin{tabular}{lcccr}
\hline $\begin{array}{l}\text { Restriction details over quantiles } \\
\text { Quantiles }\end{array}$ & Variable & Restricted value & $\chi^{2}$ statistic & Prob. \\
\hline \multirow{2}{*}{$0.1,0.9$} & IFIN & 1.811074 & 2.755659 & 0.5110 \\
& TRADE & -251062.4 & 528887.5 & 0.6350 \\
& GFCF & -1.273538 & 1.071008 & 0.2344 \\
$0.2,0.8$ & C & 205618.4 & 212921.9 & 0.3342 \\
& IFIN & -1.923864 & 2.583085 & 0.4564 \\
& TRADE & 552990.7 & 514250.1 & 0.2822 \\
& GFCF & 0.258632 & 0.988665 & 0.7936 \\
$0.3,0.7$ & C & -176477.4 & 201283.3 & 0.3806 \\
& IFIN & -1.474074 & 2.065111 & 0.4754 \\
& TRADE & 398324.5 & 390078.9 & 0.3072 \\
$0.4,0.6$ & GFCF & 0.160445 & 0.813010 & 0.8436 \\
& C & -117727.9 & 159040.2 & 0.4592 \\
& IFIN & -0.384027 & 2.554144 & 0.8805 \\
& TRADE & -37899.06 & 356957.0 & 0.9154 \\
& GFCF & 0.092605 & 1.123850 & 0.9343 \\
& C & 37961.63 & 153014.4 & 0.8041
\end{tabular}

Source(s): Authors' own
Islamic finance and economic growth
Table 6.

Markov chain marginal bootstrap (MCMB-A) quantile regression diagnostics

slope equality is rejected at the significance level of $5 \%$ based on the Wald test). Thus, the slope equality is different across quantiles; therefore, the conditional quantile is not identical.

Table 6 also reports that the null hypothesis of stability cannot be rejected at the significance level of $5 \%$ in Ramsey's reset stability test (1969) ( $p$-value: $0.1132>0.05$ ). Consequently, all of the coefficients on all powers are equally insignificant; therefore, the estimation model is truthful and stable against misspecifications of heteroskedasticity and autocorrelation.

Table 6 further reports that the $\mathrm{chi}^{2}$-statistic value is 12.95808 under the symmetric quantile assessment (probability of $\chi^{2}: 0.6758>0.05$ ). This indicates no existence of asymmetry across all the quantiles (0.1 and 0.9, 0.2 and 0.8, 0.3 and 0.7, 0.4 and 0.6). This is what the insignificant values confirm based on the individual coefficient restriction details across quantiles.

By executing the diagnostic examinations of Koenker and Bassett's slope equality (1982), Newey and Powell's symmetric quantile assessment (1987) and the Ramsey's Reset stability test (1969) in the MCMB-A quantile regression, this paper demonstrated that the estimated 
IJIF

14,1

outcomes are robustly precise and truthful. This answers the research question whether Islamic finance is promoting economic growth in Turkey.

\section{Conclusion}

By applying the MCMB-A quantile regression process, this paper determined that Islamic finance's influence on economic growth is statistically significant and positive in Turkey across the $0.1,0.2,0.3,0.4,0.5,0.6,0.7,0.8$ and 0.9 quantiles, which confirms that the increase of Islamic finance in Turkey is promoting economic growth.

Thus, this experimental study has achieved robust evidence that Islamic finance in Turkey is a real contribution to economic growth under the endogenous growth model of Romer (2011). The result also confirms the supply-leading hypothesis of Schumpeter (1934) and is well-matched with the financial repression philosophy of McKinnon (1973) and Shaw (1973). Additionally, the estimated outcomes validated the hypothesis that Islamic finance is positively affecting Turkish economic growth.

Therefore, this empirical research agrees with the studies of Kalaysi and Tekin (2016) and Atici (2018) that found a positive influence of Islamic finance on Turkey's economic growth. This significant contribution refers to the success of the New Turkish Economy Program (2019-2021), which aims to triple the Islamic finance share in the banking sector through PBs by 2025. It also aligns with the 11th Development Plan prepared by the Turkish Presidency's Strategy and Budget for 2019-2023, which aims to increase the share of PBs in the worldwide market (Tan, 2020). Additionally, the success of Islamic finance in promoting Turkish economic growth is because of the capabilities of the Islamic finance industry in Turkey, which is widely accepted by a noteworthy Muslim population who prefer Islamic finance to conventional banking (Hajjar, 2019).

In conclusion, this study shows the successful experiment of Islamic finance in Turkey, which can be beneficial to many countries that are still at the beginning of adopting Islamic finance as an engine of economic growth.

This paper has an implication for practice and research. It suggests the adoption of the Turkish successful experiment as an exemplary experiment in achieving economic growth through Islamic finance. To simulate this successful experiment, there must be cooperation between both decision-makers who are in the government and monetary policy adapters to make the flow of Islamic finance easy and quick through the finance channels that promote economic growth.

\section{References}

Abdel-Razzaq, A. (2018), "The determinants of Islamic banking profitability", $\mathrm{PhD}$ thesis, Western Sydney University, Penrith, NSW, available at: https://trove.nla.gov.au/version/253787515 (accessed 12 June 2020).

Abduh, M. and Omar, A.M. (2012), "Islamic banking and economic growth: the Indonesian experience", International Journal of Islamic and Middle Eastern Finance and Management, Vol. 5 No. 1, pp. 35-47.

Anwar, M.S., Junaidi, J., Salju, S., Wicaksono, R. and Mispiyanti, M. (2020), "Islamic bank contribution to Indonesian economic growth", International Journal of Islamic and Middle Eastern Finance and Management, Vol. 13 No. 3, pp. 519-532.

Atici, G. (2018), "Islamic (participation) banking and economic growth: empirical focus on Turkey", Asian Economic and Financial Review, Vol. 8 No. 11, pp. 1354-1364.

Boukhatem, J. and Moussa, F.B. (2018), "The effect of Islamic banks on GDP growth: some evidence from selected MENA countries", Borsa Istanbul Review, Vol. 18 No. 3, pp. 231-247.

Bourke, P. (1989), "Concentration and other determinants of bank profitability in Europe, North America and Australia", Journal of Banking and Finance, Vol. 13 No. 1, pp. 65-79. 
Brock, W.A. and Durlauf, S.N. (2001), "What have we learned from a decade of empirical research on growth? Growth empirics and reality", The World Bank Economic Review, Vol. 15 No. 2, pp. 229-272.

Chan, K.S. and Tong, H. (1986), "On estimating thresholds in autoregressive models", Journal of Time Series Analysis, Vol. 7 No. 3, pp. 179-190.

Durlauf, S.N. and Quah, D.T. (1999), "The new empirics of economic growth", in Handbook of Macroeconomics, Vol. 1, pp. 235-308.

Farahani, Y.G. and Dastan, M. (2013), “Analysis of Islamic banks' financing and economic growth: a

Islamic finance and economic growth Management, Vol. 6 No. 2, pp. 156-172.

Feng, X., He, X. and Hu, J. (2011), "Wild bootstrap for quantile regression”, Biometrika, Vol. 98 No. 4, pp. 995-999.

Furqani, H. and Mulyany, R. (2009), "Islamic banking and economic growth: empirical evidence from Malaysia”, Journal of Economic Cooperation and Development, Vol. 30 No. 2, pp. 59-74.

Gani, I.M. and Bahari, Z. (2021), "Islamic banking's contribution to the Malaysian real economy", ISRA International Journal of Islamic Finance, Vol. 13 No. 1, pp. 6-25. doi: 10.1108/IJIF-01-2019-0004.

Granger, C.W., Newbold, P. and Econom, J. (1974), "Spurious regressions in econometrics", in Baltagi, B.H. (Ed.), A Companion of Theoretical Econometrics, Wiley Online Library, New Jersey, pp. 557-561.

Hahn, J. (1995), "Bootstrapping quantile regression estimators”, Econometric Theory, Vol. 11 No. 1, pp. 105-121.

Hajjar, M. (2019), "Islamic finance in Europe: a cross analysis of 10 European countries", 1st ed., Springer International Publishing; Palgrave Macmillan, available at: https://www.springer.com/ gp/book/9783030040932 (accessed 22 March 2020).

Hassan, M.K., Sanchez, B. and Yu, J.S. (2011), "Financial development and economic growth: new evidence from panel data", The Quarterly Review of Economics and Finance, Vol. 51 No. 1, pp. 88-104.

He, X. and Hu, F. (2002), "Markov chain marginal bootstrap", Journal of the American Statistical Association, Vol. 97 No. 459, pp. 783-795.

Imam, P. and Kpodar, K. (2016), “Islamic banking: good for growth?”, Economic Modelling, Vol. 59, pp. 387-401.

International Monetary Fund (2020), “Turkey's GDP and components - IMF data”, available at: https://data.imf.org/regular.aspx?key $=61545852$ (accessed 8 May 2020).

Islamic Financial Services Board (2020), "Metadata (Islamic banking)", available at: https://www.ifsb. org/psifi_06.php (accessed 11 February 2020).

Jhingan, M.L. (2011), The Economics of Development and Planning, Vrinda Publications, Delhi.

Jiang, H., Zhang, J. and Sun, C. (2019), "How does capital buffer affect bank risk-taking? New evidence from China using quantile regression”, China Economic Review, Vol. 60, 10130.

Jureckova, J., Sen, P., Picek, J., Sen, P. and Picek, J. (2012), Methodology in Robust and Nonparametric Statistics, CRC Press, Boca Raton, FL.

Kalaysi, S. and Tekin, B.E. (2016), "Interactions between economic growth, FDI and Islamic banking development in Turkey", International Journal of Business and Management, Vol. 11 No. 8, pp. 230-240.

Kassim, S. (2016), "Islamic finance and economic growth: the Malaysian experience", Global Finance Journal, Vol. 30, pp. 66-76.

Keenan, D.M. (1985), "A Tukey nonadditivity-type test for time series nonlinearity", Biometrika, Vol. 72 No. 1, pp. 39-44.

King, R.G. and Levine, R. (1993), "Finance and growth: Schumpeter might be right", The Quarterly Journal of Economics, Vol. 108 No. 3, pp. 717-737. 
IJIF

14,1

Kocherginsky, M. and He, X. (2007), "Extensions of the Markov chain marginal bootstrap", Statistics and Probability Letters, Vol. 77 No. 12, pp. 1258-1268.

Kocherginsky, M., He, X. and Mu, Y. (2005), "Practical confidence intervals for regression quantiles", Journal of Computational and Graphical Statistics, Vol. 14 No. 1, pp. 41-55.

Koenker, R. and Bassett, G. (1978), "Regression quantiles”, Econometrica, Vol. 46 No. 1, pp. 33-50.

Koenker, R. and Bassett, G. (1982), "Robust tests for heteroscedasticity based on regression quantiles", Econometrica, Vol. 50 No. 1, pp. 43-61.

Koenker, R. and Machado, J.A.F. (1999), "Goodness of fit and related inference processes for quantile regression”, Journal of the American Statistical Association, Vol. 94 No. 448, pp. 1296-1310.

Lebdaoui, H. and Wild, J. (2016), "Islamic banking presence and economic growth in Southeast Asia", International Journal of Islamic and Middle Eastern Finance and Management, Vol. 9 No. 4, pp. 551-569.

Ledhem, M.A. (2020), "Does sukuk financing boost economic growth? Empirical evidence from Southeast Asia", PSU Research Review. doi: 10.1108/PRR-09-2020-0028.

Ledhem, M.A. and Mekidiche, M. (2020), "Economic growth and financial performance of Islamic banks: a CAMELS approach", Islamic Economic Studies, Vol. 28 No. 1, pp. 47-62.

Ledhem, M.A. and Moussaoui, W. (2021), "Islamic finance for entrepreneurship activities and economic growth: a parametric and non-parametric analysis from Malaysia", PSU Research Review. doi: 10.1108/PRR-02-2021-0012.

Leong, C.K. and Huang, W. (2010), "Testing for spurious and cointegrated regressions: a wavelet approach", Journal of Applied Statistics, Vol. 37 No. 2, pp. 215-233.

Levine, R. and Zervos, S. (1998), "Stock markets, banks, and economic growth", American Economic Review, Vol. 88 No. 3, pp. 537-558.

Lucas, R.E. (1988), "On the mechanics of economic development", Journal of Monetary Economics, Vol. 22 No. 1, pp. 3-42.

Machado, J.A. and Silva, J. (2013), "Quantile regression and heteroskedasticity", Department of Economics, University of Essex, available at: https://jmcss.som.surrey.ac.uk/JM_JSS.pdf (accessed 10 February 2020).

Machado, J.A., Parente, P. and Silva, J.S. (2019), "QREG2: Stata module to perform quantile regression with robust and clustered standard errors", available at: https://ideas.repec.org/c/boc/bocode/ s457369.html (accessed 10 February 2020).

McAughtry, L. (2019), "IFN annual guide 2019", REDmoney Group, available at: https://www. islamicfinancenews.com/supplements/ifn-annual-guide-2019 (accessed 2 June 2020).

McKinnon, R.I. (1973), Money and Capital in Economic Development, Brookings Institution Press, Washington, DC.

Mohd. Yusof, R. and Bahlous, M. (2013), "Islamic banking and economic growth in GCC and East Asia countries: a panel cointegration analysis", Journal of Islamic Accounting and Business Research, Vol. 4 No. 2, pp. 151-172.

Newey, W.K. and Powell, J.L. (1987), "Asymmetric least squares estimation and testing", Econometrica, Vol. 55 No. 4, pp. 819-847.

Nikitina, L., Paidi, R. and Furuoka, F. (2019), "Using bootstrapped quantile regression analysis for small sample research in applied linguistics: some methodological considerations", PloS One, Public Library of Science, Vol. 14 No. 1, pp. 1-19.

Participation Banks Association of Turkey (2017), "Participation banks 2017, TKBB", available at: https://tkbb.org.tr (accessed 12 August 2021).

Participation Banks Association of Turkey (2020), "Participation banks association of Turkey, TKBB", available at: https://www.tkbb.org.tr/en (accessed 10 October 2020). 
Participation Banks Association of Turkey (2021a), "Participation banks 2020 sector report, TKBB, Turkey", available at: https://tkbb.org.tr (accessed 5 August 2021).

Participation Banks Association of Turkey (2021b), "Participation banking strategy update report 2021-2025, TKBB”, available at: https://tkbb.org.tr (accessed 5 August 2021).

Petkovski, M. and Kjosevski, J. (2014), "Does banking sector development promote economic growth? An empirical analysis for selected countries in Central and South Eastern Europe", Economic Research-Ekonomska Istraživanja, Vol. 27 No. 1, pp. 55-66.

Rajan, R. and Zingales, L. (1996), Financial Dependence and Growth, National Bureau of Economic Research, Cambridge, MA.

Ramsey, J.B. (1969), "Tests for specification errors in classical linear least-squares regression analysis", Journal of the Royal Statistical Society: Series B (Methodological), Vol. 31 No. 2, pp. 350-371.

Romer, D. (2011), "Endogenous growth", in Advanced Macroeconomics, 4th ed., McGraw-Hill, New York, pp. 101-149.

Salaam Gateway (2020), "State of the global Islamic economy report 2019/20", available at: https:// www.salaamgateway.com/SGIE19-20 (accessed 3 January 2020).

Salaam Gateway (2021), "State of the global Islamic economy 2020/21 report", available at: https:// www.salaamgateway.com/reports/state-of-the-global-islamic-economy-202021-report-2 (accessed 19 November 2020).

Schumpeter, J.A. (1934), The Theory of Economic Development; an Inquiry into Profits, Capital, Credit, Interest, and the Business Cycle, Vol. 46, Harvard University Press, Cambridge, MA.

Shaw, E.S. (1973), Financial Deepening in Economic Development, Oxford University Press, New York.

Tabash, M.I. and Anagreh, S.A. (2017), "Do Islamic banks contribute to growth of the economy? Evidence from United Arab Emirates (UAE)”, Banks and Bank Systems, Vol. 12 No. 1, pp. 113-118.

Tan, V. (2020), "IFN annual guide 2020", REDmoney Group, available at: https://www. islamicfinancenews.com/supplements/ifn-annual-guide-2020 (accessed 2 June 2020).

Tsay, R.S. (1986), "Nonlinearity tests for time series", Biometrika, Vol. 73 No. 2, pp. 461-466.

Ullah, A. (Ed.) (1989), Semiparametric and Nonparametric Econometrics, Physica-Verlag Heidelberg, doi: 10.1007/978-3-642-51848-5.

Yüksel, S. and Canöz, I. (2017), "Does Islamic banking contribute to economic growth and industrial development in Turkey", Ikonomika, Vol. 2 No. 1, pp. 93-102.

\section{About the authors}

Mohammed Ayoub Ledhem, $\mathrm{PhD}$, is a lecturer at the University Centre of Maghnia, Department of Economics (Algeria). His research covers the areas of financial performance in Islamic banks, Islamic capital markets, advanced econometrics in Islamic banking, big data, data mining and artificial intelligence. Mohammed Ayoub Ledhem is the corresponding author and can be contacted at: ledhem. edu@gmail.com

Mohammed Mekidiche, $\mathrm{PhD}$, is a senior lecturer at the University Centre of Maghnia, Department of Economics (Algeria). He has 14 years of teaching experience at the graduate and postgraduate levels in operations research and microeconomic modeling.
Islamic finance and economic growth 